\title{
THE IMPACT OF CHANGING DETERMINATIONS OF A LOCAL SPATIAL DEVELOPMENT PLAN ON THE CADASTRAL VALUE OF REAL ESTATE ${ }^{1}$
}

\author{
Karolina Szmatloch, M.Sc. \\ Department of Geomatics \\ Faculty of Mining Surveying and Environmental Engineering \\ AGH University of Science and Technology \\ e-mail:ksobol@agh.edu.pl
}

\begin{abstract}
This paper concerns changes of the cadastral value of real estate connected with changes in the land use determinations of the local spatial development plan in a given area over the analyzed period of time.

The research has revealed a variable course of the determinations of adopted local plans over the years, which would indicate the need to re-appraise the cadastral value of real estates, as well as recharge the tax ad valorem. To demonstrate the effects of the identified changes in spatial development plans in accordance with the assumptions of mass appraisal, the cadastral value of sample real estates located in the area of research was determined. The real estates were covered by a change of intended use resulting from adopting the Local Spatial Development Plan for the City of Krakow. The conducted research confirmed a significant change in the cadastral value of real estates subjected to evaluation.

In addition, the characteristics of the knowledge base on real estates on the local market of the City of Krakow have been researched, and the valid legal acts regarding the connection of information contained in the local spatial development plan with the method of determining the cadastral value of a real estate have been analyzed.
\end{abstract}

Key words: mass real estate appraisal, change of the cadastral value, spatial development.

JEL Classification: R52, R30.

Citation: Szmatloch K., 2015, The Impact of Changing Determinations of a Local Spatial Development Plan on the Cadastral Value of Real Estate, Real Estate Management and Valuation, Vol. 23, No. 4, pp. 16-23.

DOI: 10.1515/remav-2015-0032

\section{Introduction}

The notion of mass real estate appraisal should be understood as an administrative and legal system of determining property tax, which the estimation of cadastral value is a necessary component of.

In order to determine the cadastral value of a real estate, we need a uniform way of operation on a national scale. This system, in its operation, should anticipate the ongoing changes regarding the form of spatial development, changes in both the spatial planning of municipalities and the means of using real estates by owners. Furthermore, one of the elements of the system should contain formulated criteria of the importance of including changes in the value of real estate, depending on the degree in which the real estate is covered by the changes in the spatial development plan.

\footnotetext{
1 The task was carried out within the scope of the Dean's Grant of the Department of Geomatics, Faculty of Mining Surveying and Environmental Engineering, AGH Krakow, Poland.
} 
Spatial planning aims to introduce spatial order and balance. Local spatial development plans are among the most valuable acts of local law for investors, owners and entrepreneurs. Furthermore, they are used in processes related to real estate management. They include some of the most important pieces of information about real estate for property experts.

Legal assumptions of mass real estate appraisal are based on the conditions of spatial development and define its elements. However, they do not specify a procedure in the case of possible changes of these determinants in the subsequent years.

This article is an attempt to present the impact of the changing conditions of spatial development on the cadastral value of analyzed real estates. The deliberations are supported by a specific example on a representative real estate market of the city of Krakow.

\section{Binding legal regulations}

The cadastral value of a real estate is obtained in the process of mass appraisal of the real estate and is, by definition, the basis for calculating the tax ad valorem, which would replace the currently used taxation system.

In Poland, the issue of mass real estate appraisal is regulated by the following legal acts: the Act of $21^{\text {st }}$ August 1997 on Real Estate Management ${ }^{2}$ and the Regulation of the Council of Ministers of 29th June

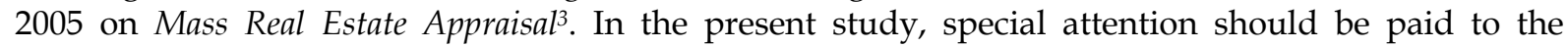
provisions of the Regulation which assume that there is an unbreakable connection between data in local spatial development plans of municipalities, and the process of mass real estate appraisal. Apart from the records of the local spatial development plan, in the present legal situation of planning processes we can also identify: the study of conditions and directions of development (which is not an act of local law) and decisions on land development and management conditions. However, in the process of mass real estate appraisal, the legislator requires information taken from the local spatial development plan (miejscowy plan zagospodarowania przestrzennego - mpzp) and, such does not exist, from the current form of use.

Spatial planning itself is regulated with the provisions of the Act of 27th March 2003 on Spatial

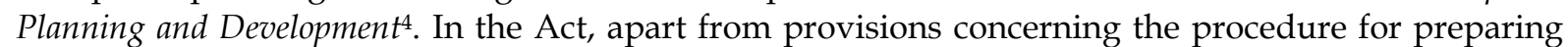
the local spatial development plans, as well as, among others, the evaluation of their topicality, in Article 36, the legislator envisaged a way of conduct in the case of the value of real estates increasing or decreasing as a result of the adoption or change of plan. The change in the value of the real estate corresponds to the issue of planning fees. There is no direct reference to changes of the cadastral value, which is variable by definition and depends largely on many factors, including the intended use in the local plan. A consequence of these changes should be the automatic re-appraisal of the cadastral value, which is a direct premise for the modification of the tax ad valorem of a particular real estate, taking account the new legal status and intended use in the local plan or change of this plan. Based on the same legal acts, without a sufficient understanding of the idea of mass real estate appraisal and the application of guidelines of conducting mass real estate appraisal, we can get an impression that the acts are imprecise. Furthermore, in order to determine the method of conduct in cases of changes of the intended use in the local plans, a special way of determining the cadastral value of the real estate subject to the assumptions of mass appraisal should be defined.

In the idea of mass real estate appraisal, two types of lands are distinguished: developed or intended for development, and undeveloped agricultural and forest land, as well as intended for purposes other than agriculture, for buildings and premises separately; this should be understood as the separation of the land from its constituent parts. The basis of fixing the cadastral value is the estimation of a representative real estate for different types of real estates in a given appraisal zone, in the area of a given registry unit. On this basis, the value of all real estates in this zone is defined. The appraisal unit for the land is a registered plot or part of it, characterized by a different intended use or a different way of use in the local spatial development plan. For the component parts of land, the appraisal unit is, by definition, a building, premise or other equipment permanently associated with the land. The appraisal zone is a continuous land area, defined on the basis of identical intended use in the local development plan and similarity of features influencing its value. More than a decade ago,

\footnotetext{
2 Journal of Laws 2010 No. 110 item 651.

3 Journal of Laws 2012 item 647.

4 Journal of Laws 2003 No. 80 item 717.
} 
a project of guidelines for conducting mass real estate appraisal (TELEGA, BOJAR, ADAMCZEWSKI, 2002) was established, with the methods of determining the cadastral value also suggested earlier (e.g. BARAŃSKA 2012, SAWIEOW 2008). They are based on the assumptions formulated in legal acts.

The control instruments, which could be used in order to re-appraise the established cadastral values, should also be mentioned. Both the main legal acts stipulate the verification and possible reappraisal of cadastral values established for all real estates in a period of 5 years from the end of the appraisal, and, at the same time, an annual control of at least $20 \%$ of the area, on subsequently selected territories of a given municipality. Such principles of control do not guarantee the identification of all changes related to the adoption or change of the local spatial dvelopment plan. The most important consequence of not accepting these changes is the incorrect charging of tax ad valorem in a given fiscal year. Furthermore, the Act on Real Estate Management envisages only the annual re-appraisal of cadastral values using the coefficients announced by the President of the National Statistical Office in the "Polish Monitor" ("Monitor Polski"). An additional problem may be the fact that conducting mass real estate appraisal on the terms of mass appraisal must apply to the area of the entire country. There is an exemption that enables appraisal to be conducted within a municipality, but it must apply to its entire area. This can constitute an additional impediment in the event when a change of the plan applies only to a part of the municipality (or selected real estates). This would generate costs resulting from financing the action from the budgets of municipalities. A solution could be the individual reappraisal of the cadastral value, performed at the request of the person in question or ex officio (KRAWCZYK 2009).

\section{Change of planning conditions on the example of the City of Krakow}

Spatial planning conditions change, and this may have effects not stipulated by legal acts regarding mass appraisal. However, in practice, the methods of revaluating the cadastral value should be developed with regard to the ongoing planning of works. Only when the local spatial development plan comes into effect may it become a legal basis for starting relevant activities with regard to the change of cadastral values of real estates. It should be remembered that the prepared plan may not come into effect for various reasons, such as: an inconsistency with the law or being repealed by the decision of the Governor. As a result of the above, the need for adjustment to the pace of planning changes, i.e. a method for the re-appraisal of fees according to the changed cadastral value of a real estate which can be updated on an annual basis, appears. In order to emphasize the changing planning situation in a given area, the intended use of real estates in the local spatial development plans of the City of Krakow in the years 1967-2015 were examined for a area of one of the city's districts.

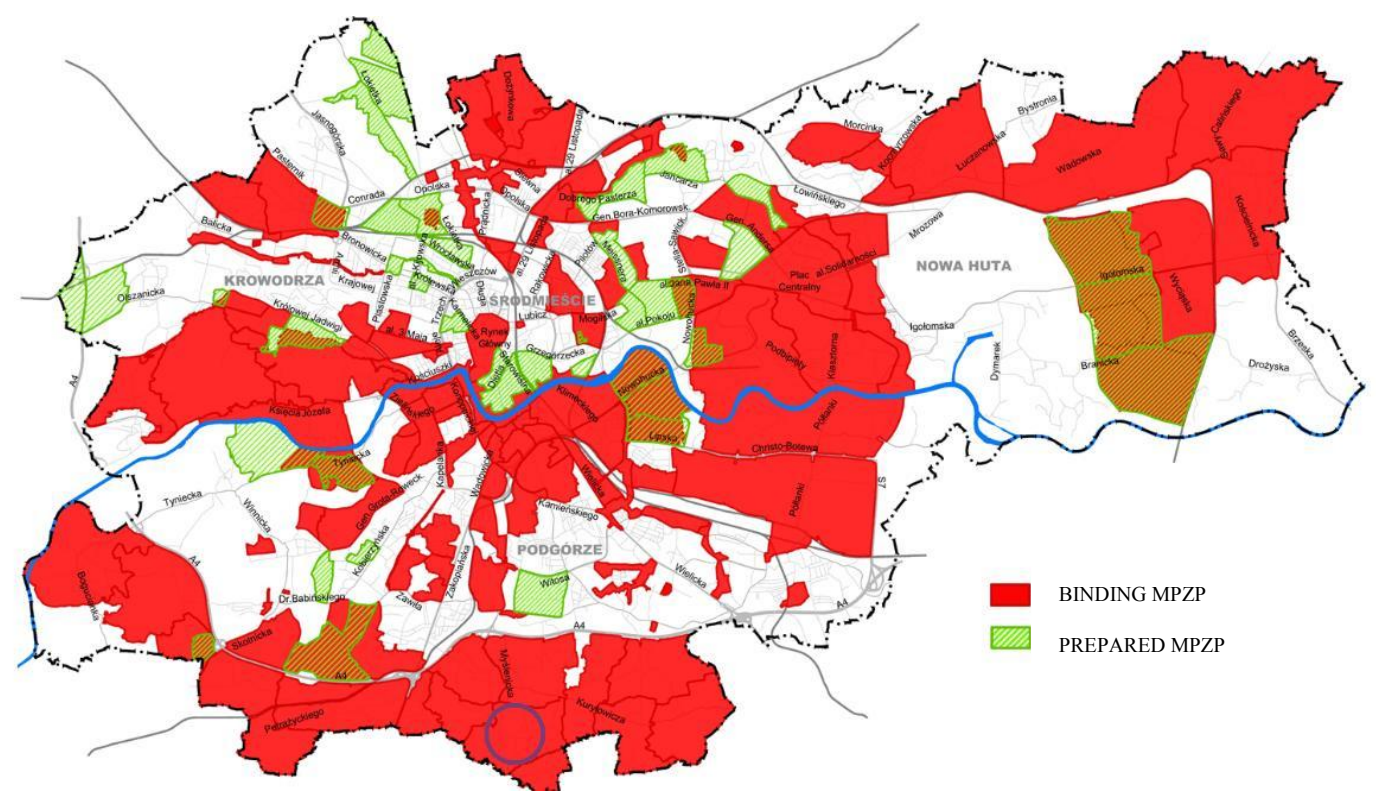

Fig. 1. A representation of valid spatial development plans for the City of Krakow. Source: Spatial Planning Office of the City of Krakow. 
The planning actions in Krakow, since the second half of 2014, have constituted the beginning of the preparation of 41 local plans. At present, 136 such studies are in force. They cover $49.4 \%$ of the area of Krakow. Figure 1 presents the current progress in the planning works.

The area, from which real estates for the examination of potential changes in the local spatial development plan have been selected, constitutes the territory of Wróblowice under the registry unit of Podgórze, districts X and XI. Access to information on the planning works within the city of Krakow is simplified thanks to the internal organizational unit of the Krakow Municipal Office, namely the Spatial Planning Office. The unit is responsible for, among others: preparation of drafts of local development plans and changes in the local spatial development plans, running and updating the register of local plans and studies, archiving planning documentation, and cooperation with the government and local government administration bodies in the field of spatial planning. As the Spatial Planning Office makes the information available in electronic form, the initial selection of plots for which a change related to the adoption of a local spatial development plan is possible has been made on the basis of a visual comparison of a previous plan and the currently valid version for the given area. On the basis of a detailed archival plan, binding in the period 1994-2000, and the currently valid plan (since 2010), the plots for which a significant change in the intended use could have potentially occurred have been visually selected. The course of planning changes for five sample real estates over the years 1967-2015 has been presented in Table 1.

Table 1

Planning conditions for selected plots from the area of Wróblowice

\begin{tabular}{|c|c|c|c|c|c|}
\hline Duration & $545 / 1$ & $381 / 24$ & $344 / 2$ & $346 / 7$ & 205 \\
\hline $\begin{array}{l}04.1967- \\
06.1977\end{array}$ & \multicolumn{5}{|c|}{ Not subject to the arrangements of mpzp } \\
\hline $\begin{array}{l}06.1977- \\
06.1988\end{array}$ & $\begin{array}{l}\text { Areas of crop } \\
\text { fields }\end{array}$ & $\begin{array}{l}\text { Areas of crop } \\
\text { fields }\end{array}$ & $\begin{array}{l}\text { Low-intensity } \\
\text { housing areas }\end{array}$ & $\begin{array}{l}\text { Low-intensity } \\
\text { housing areas }\end{array}$ & $\begin{array}{l}\text { Parks, lawns and } \\
\text { crop fields/low- } \\
\text { intensity housing } \\
\text { areas }\end{array}$ \\
\hline $\begin{array}{l}06.1988- \\
06.1993\end{array}$ & $\begin{array}{l}\text { Horticultural } \\
\text { cultivations } \\
\text { and orchards } \\
\text { without the } \\
\text { right of } \\
\text { development }\end{array}$ & $\begin{array}{l}\text { Meadows } \\
\text { and pastures }\end{array}$ & $\begin{array}{l}\text { Meadows and } \\
\text { pastures / low } \\
\text { intensity } \\
\text { detached } \\
\text { housing areas }\end{array}$ & $\begin{array}{l}\text { Meadows and } \\
\text { pastures }\end{array}$ & $\begin{array}{l}\text { Areas of field } \\
\text { crops without the } \\
\text { right of } \\
\text { development/ } \\
\text { detached } \\
\text { housing areas }\end{array}$ \\
\hline $\begin{array}{l}06.1993- \\
12.1994\end{array}$ & $\begin{array}{l}\text { Agricultural } \\
\text { area }\end{array}$ & $\begin{array}{l}\text { Agricultural } \\
\text { area }\end{array}$ & $\begin{array}{l}\text { Agricultural } \\
\text { area/housing } \\
\text { area }\end{array}$ & $\begin{array}{l}\text { Agricultural } \\
\text { area }\end{array}$ & $\begin{array}{l}\text { Agricultural/ } \\
\text { housing area }\end{array}$ \\
\hline $\begin{array}{l}12.1994- \\
01.2003\end{array}$ & $\begin{array}{l}\text { Horticultural } \\
\text { cultivations } \\
\text { and orchards } \\
\text { without the } \\
\text { right of } \\
\text { development }\end{array}$ & $\begin{array}{l}\text { Low } \\
\text { intensity } \\
\text { detached } \\
\text { housing } \\
\text { areas }\end{array}$ & $\begin{array}{l}\text { Area of crop } \\
\text { fields without } \\
\text { the right of } \\
\text { development }\end{array}$ & $\begin{array}{l}\text { Area of crop } \\
\text { fields without } \\
\text { the right of } \\
\text { development }\end{array}$ & $\begin{array}{l}\text { Area of crop } \\
\text { fields without the } \\
\text { right of } \\
\text { development }\end{array}$ \\
\hline $\begin{array}{l}01.2003 \text { - } \\
10.2010\end{array}$ & \multicolumn{5}{|c|}{ The plot was not subject to the arrangements of any mpzp } \\
\hline $\begin{array}{l}\text { since } \\
10.2010\end{array}$ & $\begin{array}{l}\text { Commercial } \\
\text { services } \\
\text { development } \\
\text { areas }\end{array}$ & $\begin{array}{l}\text { Areas of } \\
\text { detached } \\
\text { residential } \\
\text { buildings }\end{array}$ & $\begin{array}{l}\text { Areas of } \\
\text { detached } \\
\text { residential } \\
\text { buildings }\end{array}$ & $\begin{array}{l}\text { Detached } \\
\text { housing areas }\end{array}$ & $\begin{array}{l}\text { Agricultural } \\
\text { areas/detached } \\
\text { housing areas }\end{array}$ \\
\hline
\end{tabular}

Source: prepared by the author.

The received data are fully credible and present changes in the directions of spatial development for the city of Krakow. During the analysis of the obtained data, it was noticed that a significant change in the intended use occurred at the time of adopting a new local spatial development plan on 
the $24^{\text {th }}$ of October 2010. In terms of the market value and the theoretical cadastral value, the differences in the intended development will determine a change in the value of these real estates. At the same time, if such a situation takes place shortly after conducting mass real estate appraisal, the appraisal unit for the given plots will change. Therefore, the cadastral value itself should definitely be re-appraised, and the tax calculated anew. The case can be additionally complicated when a given real estate (plot), so far having a uniform intended use, will have two or more purposes as a result of the adoption of a new plan or a change of it, which will result in a breakdown into other appraisal units.

\section{Methods of determining the cadastral value of lands under different planning conditions, along with an example of their application}

The value of lands is strictly correlated with their intended use (CYMERMAN, 2006). Therefore, a change in the value of the land itself will substantially change the theoretical cadastral value of the whole real estate. The issue of the change in the value of real estate under different planning conditions has already been discussed, among others by (KRAJEWSKA, 2008). The author presents methods of determining the value of a real estate under different planning conditions, along with examples of their application. In the regulation on mass real estate appraisal, we read that the cadastral value of a real estate consists of:

1) the appraisal unit value, if the unit constitutes the entire real estate;

2) the sum of values of appraisal units, if each of the units constitutes only a part of the real estate, or if they are individual components of the land.

According to (BARAŃSKA 2012), dividing the land into its constituent parts may be an additional difficulty in the process of determining the cadastral value of a real estate. The difficulty results from provisions in the regulation concerning the relation of cadastral values of real estates to market prices. However, we know that the market value of a real estate is its most likely price possible to be obtained on the market. It often results directly from the prices of sold real estates, constituting the price of the entire real estate, without distinguishing the land and its components. In accordance with the idea of mass real estate appraisal, when analyzing possible changes of cadastral values of a real estate under different planning conditions, particular attention should be paid to the value of the land (in a situation when the land has component parts), because the change of spatial conditions alters the cadastral value of the entire real estate. In the proposed method, the sought re-appraised cadastral value of a real estate shall be the sum of the values of land components and the value of the land subjected to the new conditions of urban planning (if the previous intended use or way of use have changed). It is assumed that the re-appraised cadastral value of a real estate will be determined as of the effective date of the change in the current intended use, which will result in charging the taxpayer with a tax recalculated ad valorem. This can be expressed by the formulas:

$$
\begin{aligned}
& W K_{1}=W K g_{1}+W K s \\
& W K_{2}=W K g_{2}+W K s
\end{aligned}
$$

where:

$W K_{1} \quad$ - cadastral value of the real estate, determined in the process of mass appraisal, taking account of the binding intended use in the mpzp or the current use,

$W \mathrm{Kg}_{1}, W \mathrm{Kg}_{2} \quad$ - the cadastral values of the ground (the sum of particular cadastral units within a given plot) before and after the change of intended use,

WK $s \quad$ - cadastral value of the component parts of land,

$W_{2} \quad$ - re-appraised cadastral value (re-appraisal associated with a change in the previous intended use of a particular real estate or its way of use).

Determination of the cadastral value of two selected land properties under different planning conditions, which are not developed and have no other components, was performed on the basis of an algorithm of mass appraisal, consistent with the one proposed in (BARAŃSKA 2012). Successively:

1) In the area of research, a set of representative undeveloped real estates was determined for the adopted appraisal zone. These were also divided into real estates intended for development and those meant for agriculture. They were selected from the collection of data on transactions from 2008-2010, gathered in the Register of Prices and Values of real estates, made available by the Municipal Office of Krakow.

2) The selected real estates were described using the characteristics listed in the Regulation on Real 
Estate Mass Appraisal and features characteristic for a given area. The values of the real estate characteristics have been expressed with an integer, in the respective scale adjusted to a given attribute:

a) for undeveloped lands intended for development, the following set of characteristics was determined: location, environment, infrastructure installations, transport access, investment possibilities, surface area.

b) for undeveloped lands intended for agriculture, the following characteristics have been considered: location, soil class, type of use, infrastructure devices used for agricultural production, surface area.

3) The two following tables constitute a fragment of the list of appraisal zones prepared in accordance with the Regulation on Mass Real Estate Appraisal. They apply to a zone, from which the collected knowledge base about the analyzed real estates and single selected real estate considered by the author as representative for this zone, come. The unit value of $1 \mathrm{~m}^{2}$ of the real estate considered as representative was determined using the method of average price correction. A description of the real estate representative for lands intended for development and the value of $1 \mathrm{~m}^{2}$ have been presented in Table 2. The description of lands intended for agriculture has been presented in Table 3.

Table 2

Description of a representative land property and calculated corrective coefficients Type of land: lands intended for development

\begin{tabular}{|c|c|c|c|c|c|c|}
\hline \multirow[t]{3}{*}{$\begin{array}{l}\text { Appraisal } \\
\text { zone ID }\end{array}$} & \multirow[t]{3}{*}{$\begin{array}{l}\text { Precinct } \\
\text { identifier }\end{array}$} & \multirow{3}{*}{$\begin{array}{l}\text { Value of } 1 \mathrm{~m}^{2} \text { of } \\
\text { a representative } \\
\text { real estate }\end{array}$} & \multicolumn{3}{|c|}{$\begin{array}{c}\text { characteristics of } \\
\text { representative real estate }\end{array}$} & \multirow[t]{2}{*}{$\begin{array}{c}\text { Corrective } \\
\text { coefficients } k_{j}\end{array}$} \\
\hline & & & Ref. & Name & $\mathrm{a}_{\mathrm{R}}$ & \\
\hline & & & 1 & Location & 2 & 0.00 \\
\hline \multirow{5}{*}{1} & \multirow{5}{*}{92} & \multirow{5}{*}{261.22} & 2 & Environment & 2 & 12.16 \\
\hline & & & 3 & Transport access & 3 & 22.58 \\
\hline & & & 4 & $\begin{array}{l}\text { Investment } \\
\text { possibilities }\end{array}$ & 2 & 34.74 \\
\hline & & & 5 & $\begin{array}{l}\text { Infrastructure } \\
\text { installations }\end{array}$ & 4.5 & 29.87 \\
\hline & & & 6 & Surface area & 9 & 0.62 \\
\hline
\end{tabular}

Source: prepared by the author.

Description of a representative land property

Table 3

Type of land: lands intended for agriculture

\begin{tabular}{|c|c|c|c|c|c|c|}
\hline \multirow[t]{4}{*}{$\begin{array}{l}\text { Appraisal } \\
\text { zone ID }\end{array}$} & \multirow[t]{4}{*}{$\begin{array}{l}\text { Precinct } \\
\text { identifier }\end{array}$} & \multirow{4}{*}{$\begin{array}{l}\text { Value of } 1 \mathrm{~m}^{2} \text { of } \\
\text { a representative } \\
\text { real estate }\end{array}$} & \multicolumn{3}{|c|}{$\begin{array}{c}\text { A representative real estate } \\
\text { characteristics }\end{array}$} & \multirow[t]{3}{*}{$\begin{array}{l}\text { Corrective } \\
\text { coefficients } k_{j}\end{array}$} \\
\hline & & & Ref. & Name & $\mathrm{a}$ & \\
\hline & & & & & $\mathrm{R}$ & \\
\hline & & & 1 & Location & 2 & 0.00 \\
\hline \multirow{5}{*}{1} & \multirow{5}{*}{92} & \multirow{5}{*}{28,28} & 2 & Soil class & 1 & 22.35 \\
\hline & & & 3 & Type of use & 2 & 0.00 \\
\hline & & & 4 & Infrastructure & 1 & 3.96 \\
\hline & & & & $\begin{array}{l}\text { installations used } \\
\text { for agricultural } \\
\text { production }\end{array}$ & & \\
\hline & & & 5 & Surface area & 19 & 2.55 \\
\hline
\end{tabular}

Source: prepared by the author.

4) Real estates 344/2 and 346/7 from Table 1 have been described in two ways:

a) as land properties intended for agriculture and forest lands (original planning conditions),

b) as land properties intended for development (updated/changed planning conditions). 
Corrective coefficients $k_{j}$ (Tab. 2, Tab. 3) were calculated on the basis of a sample algorithm of determining the value of a real estate using the method of average price adjustment, which belongs to the comparative approach. The coefficients, which correct the average price occurring in the selected appraisal zone with regard to differences in the attributes of the evaluated real estates and the adopted representative real estate, were determined according to the following formula:

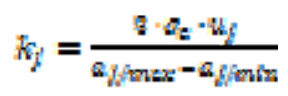

where:

$\sigma_{c} \quad-$ standard deviation of the prices of representative real estates in a given zone

$u_{j} \quad-$ weight of the attribute $j$ in explaining the prices of real estates in a given zone

$a_{j / m a x}, a_{j / \min } \quad$ - extreme values of the attribute $j$ in a given appraisal zone

Finally, on the basis of the calculated corrective coefficients and with regard to the characteristics of the representative real estate, the cadastral value in the original and updated conditions has been determined, according to the following formula:

$$
W_{i K}=W_{R}+k_{1}\left(a_{1}-a_{1 R}\right)+k_{2}\left(a_{2}-a_{2 R}\right)+\ldots+k_{s}\left(a_{s}-a_{1 R}\right)
$$

where:

$W_{R} \quad$ - value of $1 \mathrm{~m}^{2}$ of the representative real estate,

$k_{1}, k_{2} \ldots k_{s} \quad$ - corrective coefficients $k_{j}$ calculated according to the formula (3),

$a_{1}, a_{2}, \ldots a_{s} \quad$ - characteristics of the evaluated real estate,

$a_{1 R}, a_{2 R}, \ldots a_{S R} \quad$ - characteristics of the representative real estate.

The results of the performed estimates have been presented in Table 4 .

Table 4

Cadastral values under different planning conditions

\begin{tabular}{cccc}
\hline Plot number & $\begin{array}{c}\text { Type of cadastral } \\
\text { value }\end{array}$ & Symbol & $\begin{array}{c}\text { Value of the real } \\
\text { estate [PLN] }\end{array}$ \\
\hline $344 / 2$ & Original & $W K_{1,344 / 2}$ & 71000 \\
\hline $344 / 2$ & Re-appraised & $W K_{2,344 / 2}$ & 223000 \\
\hline $346 / 7$ & Original & $W K_{1,346 / 7}$ & 62000 \\
\hline $346 / 7$ & Re-appraised & $W K_{2,346 / 7}$ & 191000 \\
\hline
\end{tabular}

Source: prepared by the author.

\section{Applications}

The presented example proves that there is a significant relation between changes in planning conditions and the cadastral value of a real estate. The adoption or change of a plan calls for carrying out the valorization of property tax.

In the present planning situation, characterized by continuous transformations, new plans are being adopted for selected districts of Krakow and past plans are being altered. This process may result in a number of effects, not only in the year of conducting the mass real estate appraisal but, above all, in the future years of control. The most comfortable solution would be to complete the planning works before the announcement of the Resolution on Conducting Mass Real Estate Appraisal. Furthermore, the author indicates the need for integrating the systems of information on real estate as a preparation process for carrying out mass appraisal.

The re-appraised cadastral value of sample plots demonstrated a threefold increase in relation to the cadastral values of the real estates determined on the basis of the intended use of the area assumed before the adoption of the now valid spatial development plan for the City of Krakow in 2010. This example only confirms the fact that the ongoing planning changes will affect the cadastral values of real estates in the areas covered by these changes. The problem may become more complex, since the lack of relevant guidelines on conducting mass appraisal may result in objections from real estate owners, which may ultimately generate problems with financing the mass appraisal. Furthermore, it has been proven that the local spatial development plan (mpzp) is a necessity, and one of the fundamental sources of information about real estate when performing evaluations for the purpose of mass real estate appraisal. The lack of guidelines supporting mass appraisal for the purpose of 
estimating cadastral values of real estates may also generate the risk of losses or difficulties with financing projects for the municipal budgets.

The author suggests the development of a way of conduct for areas where changes of intended use are planned, knowing the course of planning works in the given area. The issue may turn out to be even harder because valid legislation in this respect does not specify such cases. Therefore, present legal acts should receive new, detailed wording.

In further research concerning the impact of changes in the determinations of the local spatial development plan on real estate value, an attempt shall be made to develop criteria of the importance of including changes in the local spatial development plan when determining the value of a real estate, depending on the surface area of the land with a changed intended use and the nature of the changes, using statistical methods. One of the elements will be (by analogy to those presented in this article) the consideration of provisions of the local spatial development plans and local market tendencies as major factors affecting the estimated value.

\section{References}

BARAŃSKA A., 2013, Real Estate Mass Appraisal in selected countries - functioning systems and proposed solutions, Olsztyn, Real Estate Management and Valuation, vol. 21, No. 3, pp. 35-42

BARAŃSKA A., 2012, Mass Appraisal of Real Estate in Poland - legal basis and practice implementation, Cyprus, International workshop on mass appraisals, pp. 14-16, September 2012.

CYMERMAN R. AND OTHERS, 2006, Planowanie przestrzenne dla rzeczoznawców majątkowych, zarządców oraz pośredników w obrocie nieruchomościami (Spatial Development for the Property Experts, Administrators and Real Estate Agents), Olsztyn, EDUKATERRA, p.47.

GNAT S., 2008, Propozycja zastosowania wybranych metod badan operacyjnych do ustalania stawki podatku katastralnego (Proposal of using selected operational research methods to determine cadastral tax rate), Olsztyn, Studia i materiały Towarzystwa Naukowego Nieruchomości (Studies and materials of Real Estate Scientific Society), vol. 16, no. 3, p. 115.

KRAJEWSKA M., 2011, Uwarunkowania planistyczne a wartość nieruchomości na rynku (Planning Conditions and the Value of Real Estate on the Market) [in]: Siemińska E. (ED.), Inwestowanie na rynku nieruchomości (Investment on the Real Estate Market), Warszawa, POLTEX, pp. 149-179.

KRAJEWSKA M., 2008, Wartość nieruchomości zabudowanej w różnych stanach planistycznych (Value of a Developed Real Estate under Different Planning Conditions), Olsztyn, Studia i Materiały Towarzystwa Naukowego Nieruchomości, Vol. 16, No. 18, p. 49.

KRAWCZYK M., 2009, Powszechna taksacja nieruchomości - istota i znaczenie (Mass Real Estate Appraisal Essence and Meaning), Ruch Prawniczy, Ekonomiczny i Socjologiczny, Vol. 3, pp.49-67.

SAwiŁow E., 2008, Metodyka ustalania wartości katastranych (Methods of Determining Cadastral Values). Olsztyn, Studia i materiały Towarzystwa Naukowego Nieruchomości, Vol.16, No. 18, p. 91.

TELEGA T., BOJAR Z., ADAMCZEWSKI Z., 2002, Guidelines of conducting mass real estate appraisal, Przegląd Geodezyjny, No. 6.

WALACIK M., CELLMER R., ŹRÓBeK S., 2013, Mass appraisal - international background, Polish solutions and proposal of new methods application, Geodetski list, Vol. 67 (90), No.4, pp. 255-269.

WOLNY A., ŹRÓBEK R., 2012, Proces przekształcania przestrzeni na obszarach o największej aktywności na rynku nieruchomości (Process of Converting Space in Areas with the Greatest Activity on the Real Estate Market), Olsztyn, Studia i Materiały Towarzystwa Naukowego Nieruchomości, Vol. 20, No. 2, pp. 33-46.

Act of 21 $1^{\text {st }}$ August 1997 on Real Estate Management, Journal of Laws 2010 No. 110 item 651 (consolidated text).

Act of 27th March 2003 on Spatial Planning and Development, Journal of Laws 2012 item 647 (consolidated text).

Regulation of the Council of Ministers of 21 ${ }^{\text {st }}$ September 2004 on Real Estate Appraisal and Preparation of Appraisal Report, Journal of Laws 2004 No. 207 item 2109.

Regulation of the Council of Ministers of 29th June 2005 on Mass Real Estate Appraisal, Journal of Laws 2005 No. 131 item 1092.

Register of Prices and Values kept by the Municipal Office in Kraków. 